\title{
Öğrencilerin Okuma ve Kütüphane Kullanma Alışkanlıklarında Ebeveynlerin Duyarlılığı
}

\author{
Sensitivities of the Parents on the Reading and Library Use \\ Habits of the Students
}

Bülent Yılmaz*

Öz

Bu çalışmada, Ankara'daki 8 merkez ilçede okuyan ilköğretim 5. sınıf öğrencilerinin okuma ve kütüphane kullanma alışkanlıklarında ebeveynlerinin duyarıııkları araştııımıştır. 344 öğrenciye uygulanan anket ile elde edilen araştırma sonuçlarına göre, ebeveynlerin bu konuda yeterince duyarlı davranmadıkları, bunun da çocuklarının okuma ve kütüphane alışkanlıklarını olumsuz yönde etkilediği saptanmıştır.

Anahtar sözcükler: Öğrenciler, Okuma alışkanlığı, Kütüphane kullanma alışkanlığı, Ebeveyn duyarlılı̆ı.

\begin{abstract}
In this research, the sensitivities of the parents on the reading and library use habits of their children in the fifth grade of primary schools in 8 central districts of Ankara was studied. The mentioned research was based on the results obtained through a questionnaire survey filled out by 344 fifth grade students, it was found out that parents are not adequately sensitive to their children's reading and library use habits and this inclination affects the habits of the students negatively.
\end{abstract}

Keywords: Students, Reading habits, Library use habits, Parents' sensitivity.

\footnotetext{
`Doç. Dr.; Hacettepe Üniversitesi Edebiyat Fakültesi Bilgi ve Belge Yönetimi Bölümü 06532 Beytepe-Ankara (byilmaz@hacettepe.edu.tr).
} 


\section{Giriş}

Bireyin bir gereksinim olarak algılaması sonucu okuma eylemini sürekli, düzenli ve eleştirel bir biçimde gerçekleştirmesi okuma alışkanlığı olarak tanımlanabilir. Benzer bir yaklaşımla, kütüphane kullanma alışkanlığı, bireyin, zihinsel gereksinimini karşılamak amacıyla bir kütüphaneyi sürekli ve düzenli olarak kullanması anlamına gelmektedir. Duyarlılık kavramı da, "duyum ve duyguları algılayabilme yeteneği, hassasiyet... duyarlı olma durumu" (Türk Dil Kurumu [TDK], 1983, s. 338) biçiminde tanımlanabilir. Gerek okuma, gerekse kütüphane kullanma alışkanlığındaki süreklilik ve düzenlilik kavramları genelde okunan kitap ya da kütüphaneye gitme sayısı temelinde değerlendirilmektedir. American Library Association [ALA] (1978, s. 3)'nın bu konuda önerdiği sıklıklardan yararlanarak sözü edilen alışkanlıklar için bu çalışmada şu düzeyler belirlenmiştir:

Zayıf alışkanlık:

Orta düzey alışkanlık:

Güçlü alışkanlık:
Yılda 1-5 kitap okuma

Yılda 1-5 kez kütüphaneye gitme

Yılda 6-11 kitap okuma

Yılda 6-11 kez kütüphaneye gitme

Yılda 12 kitap ve daha fazla okuma

Yılda 12 kez ve daha fazla kütüphaneye gitme

Bir çocuğun okuma ve kütüphane kullanma alışkanlıklarını kazanıp, geliştirmesinde birçok bireysel ve toplumsal etken rol oynamaktadır. Bu alışkanlıklarda bir ülkedeki kültür yapısı, eğitim sistemi, düşünce özgürlüğü, medya gibi toplumsal etkenlerin yanı sıra aile, öğretmen, kütüphaneci, arkadaş grubu gibi, yakın çevrenin etkisi de söz konusu olmaktadır. Özellikle öğretmenkütüphaneci iletişimi bu alışkanlıklar açısından "klasik" olarak nitelenebilir. Bu anlamda, okul-aile derneklerinin etkinlikleri, halk ve okul kütüphanelerinin hizmetlerini planlarken aile ve öğretmenlerden yararlanması, halk kütüphanelerinin ebeveynleri, çocuklarının okuma alışkanlıklarını nasıl geliştirebilecekleri konusunda bilgilendirmesi (Terweilliger, 1984) noktasında ebeveyn-kütüphaneci-aile-öğretmen ilişkisi sık rastlanan ilişki türleridir. Bu çalışma, sıralanan bu etkenlerden aileyi, inceleme konusu olarak ele almaktadır. 
Çocuğun kişilik kazanmasında ve toplumsallaşmasında en önemli kurum olan aile her açıdan belirleyici ilk toplumsal çevredir. Bütün alışkanlıklarda olduğu gibi okuma ve kütüphane kullanma alışkanlıklarının kazanılmasında da ailenin yaklaşım ve tutumu, diğer bir deyişle duyarlıığı başlıca etkendir. Powell, Taylor ve McMillan (1984), yaptıkları araştırmanın sonuçlarına dayanarak, çocukların okuma ve kütüphane kullanma alışkanlıklarının geliştirilmesinde ailenin temel kurum olduğunu açık bir biçimde belirtmektedirler. Bu gerçeği, Steinberg (1979) de "çocuğun ilgili alışkanlıklarında temel etkinin aileden geldiği" biçiminde açıklamaktadır. Sağlamtunç (1991), bu konuda bir başka önemli noktayı vurgularken, ailenin okuma ve kütüphane kullanma alışkanlıkları konusunda çocuğu olumlu yönde olduğu gibi olumsuz yönde de etkileyebileceğini belirtmektedir. Ailenin, çocuğu için bu konuda yerine getirmesi gereken sorumluluklar, sorumluluk bilinci ve yapması gerekenler bu duyarlılıktan kaynaklanmaktadır. Ebeveynlerin, sözü edilen bu alışkanlıklar konusunda yapması gerekenleri, aynı anlama gelmek üzere göstermeleri beklenen duyarlılıklarını kısaca şu noktalarda toplayabiliriz:

- Bir evde okuma ortamını yaratan, diğer bir deyişle, böyle bir ortamın doğal parçası kitaplıktır. Çocukların, doğdukları andan itibaren sürekli görebilecekleri ve kullanabilecekleri bir kitaplık, çocuk için okuma alışkanlığının ruhsal ve davranışsal etkenlerinden birisi anlamına gelmektedir. Bu nedenle ebeveynler evlerinde bir kitaplık oluşturma sorumluluğuna sahiptirler.

- Okul öncesi dönemde, okuma anlamında çocuk ile kitap ilişkisini ebeveyn sağlamalıdır. Bu çerçevede, ebeveyn çocuğuna, düzeyine uygun kitaplar okumalı ve kitaplar hakkında onunla konuşmalıdır. Çocuk kitap ile ne kadar erken dönemde tanıştırılır ise, bu onun okuma alışkanlığı açısından önemli bir avantaj olmaktadır. Alpay (1991a; 1991b) okuma alışkanlığında çocukların ebeveynler tarafından kitap ile tanıştırılmasının önemine dikkat çekmektedir.

- Çocuğun okuma alışkanlığı kazanması ve geliştirmesinde ebeveyn duyarlıığının önemli boyutlarından birisi çocuğa kitap hediye etmektir. Çocuğun kitabı ve okumayı olumlu ve değerli bir eylem olarak algılanmasında, ona ebeveyni tarafından kitap hediye edilmesi küçümsenmemesi gereken bir davranıştır. Çocuğun evde belirli ölçüde hissettiği 
okuma ortamı, onu kitabevi, kitap fuarı ve kütüphane gibi yoğun okuma atmosferlerine sokarak desteklenmelidir. Bu nedenle ebeveyn okuma alışkanlığını kazanması açısından çocuğunu zaman zaman bu tür yerlere götürmelidir.

- Okuma alışkanlığına ilişkin olarak çocuğun ebeveynden en çok beklediği duyarlılık parçalarından birisi okuyacağı kitabı seçme konusunda ebeveyninin ona yardım etmesidir (Lohann, 1991). Çocuğunun ilgi ve beğenilerini en yakından bilen kişiler olarak ebeveynler bu konuda ciddi sorumluluklara sahiptirler.

- Özellikle eleştirel okuma becerisini kazanmasında okuduğu kitaplar hakkında çocukları ile konuşmaları ebeveynlerin bu alışkanlığa ilişkin önemli duyarlılık alanlarından birisidir.

- Ebeveyn önemli ve farklı bir eylem/araç olduğunu hissettirmek için çocuğuna kitap alması için para verme konusunda duyarlı davranmalıdır.

- Çocuklarının kitap okumalarına ve kütüphaneye gitmelerine ebeveynler mutlaka olumlu tepki vermelidirler. Bu konuda onları desteklemeli, övmeli ve gerekirse çeşitli biçimlerde ödüllendirmelidirler. Tepkisiz kalmak ya da olumsuz tepki göstermek çocukların okuma ve kütüphane kullanma alışkanlıkları açısından son derece tehlikeli olabilir.

- Ebeveynler çocukları için güçlü modellerdir. Çocuklar doğal olarak ebeveynlerini genelde taklit etmektedirler. Bu nedenle, ebeveynler kitap okuyarak ve kütüphaneye giderek çocuklarına bu konuda da olumlu modellik yapmalıdırlar.

- Kuşkusuz buraya kadar sıralanan ve çocukların sözü edilen alışkanlıkları kazanmalarında ve geliştirmelerinde ebeveynlerin göstermeleri gereken duyarlılığın temeli, onların öncelikle bu konuda önemli bir sorumluluğa sahip olduklarını bilmeleridir. Diğer bir deyişle, ebeveynler bu konuda öncelikle sorumluluk bilincine sahip olmalıdırlar. Çocukların okuma ve kütüphane kullanma alışkanlıklarına ilişkin ebeveyn duyarlılığı, sözü edilen "sorumluluk bilinci" anlamına gelmektedir. Bu sorumluluk bilincine, dolayısıyla duyarlılığa sahip olmayan ve bu sorumluluğu/duyarlıığı göstermeyen ebeveynlerin çocuklarının, okuma ve kütüphane kullanma alışkanlıklarını kazanma olasııkları düşecektir. 


\section{Araştırmanın Amacı ve Kapsamı}

Türkiye'de okuma ve kütüphane kullanma alışkanlığına yönelik olarak yapılan araştırmalar* içinde konuyu çocuk-ebeveyn ilişkisi ya da bütünlüğü temelinde değerlendiren çalışma azlığı araştırmamızın ana gerekçesini oluşturmuştur. Dolayısıyla bu araştırma, çocukların okuma ve kütüphane kullanma alışkanlıklarında ebeveyn duyarlıığının düzeyini ve niteliğini belirlemek amacıyla yapılmıştır. Araştırma, Ankara Büyükşehir Belediyesi sınırları içinde yer alan 8 merkez ilçede okuyan ilköğretim 5. sınıf öğrencilerini kapsamaktadır. Araştırmaya dahil edilen ilçe ve ilköğretim okulları şunlardır:

\begin{tabular}{ll} 
İlçeler & \multicolumn{1}{c}{ Okullar } \\
\hline Altındağ & Inönü İlköğretim Okulu \\
Çankaya & Mimar Kemal İlköğretim Okulu \\
Etimesgut & Bahar İlköğretim Okulu \\
Gölbaşı & Atatürk İlköğretim Okulu \\
Keçiören & Yalçın Eskiyapan İlköğretim Okulu \\
Mamak & 75. Yıl İlköğretim Okulu \\
Sincan & Semiha İsen İlköğretim Okulu \\
Yenimahalle & Barbaros İlköğretim Okulu
\end{tabular}

Araştırmaya 5. sınıf öğrencilerinin alınmasının temel nedeni, genelde ilk okul döneminin özel olarak da 5. sınıfa karşılık gelen yaş grubunun okuma ve kütüphane kullanma alışkanlıklarının kazanılması açısından son derece kritik bir dönem olarak kabul edilmesidir (Bamberger, 1990; Özen, 2001; Huttner, 1976).

Araştırmanın yapıldığı ilçelerdeki ilköğretim 5. sınıf öğrencilerinin toplam sayısı ${ }^{\star \star}$ yaklaşık $62.115^{\prime}$ dir*** $^{\star \star}$. Araştırmada anket uygulanan, diğer bir deyişle örnekleme alınan öğrenci sayısı 344'dür. 0,99 güven düzeyi ve 0,05 hoşgörü

\footnotetext{
"Bu konuda yapılan bazı araştırmaların genel bir özeti için bkz. Bayram, 2001. Ayr. bkz. Özçelebi ve Cebecioğlu, 1990; Özdemirci, 1990; Yılmaz, 1995.

${ }^{* *}$ Milli Eğitim Bakanlığı'ndan alınan istatistiklerde sınıflara göre sayısal bir dağııım yoktur. Bu ilçelerdeki toplam ilköğretim öğrenci sayısı ilköğretim 8 yıldan oluştuğu için 8'e bölünmüştür.

*** Milli Eğitim Bakanlığı Ankara II Milli Eğitim Müdürlüğü’nden 7 Mayıs 2004 tarihinde alınan bilgi.
} 
miktarına göre bu büyüklükte (62.115) kitleyi istatistiksel olarak temsil eden örneklem miktarı 338'dir (Çıngı, 1990, s. 265). Seçilen örneklem istatistiksel olarak evreni temsil etmektedir.

Uygulanan anket ile ebeveynlerin, çocuklarının okuma ve kütüphane kullanma alışkanlıklarına yönelik duyarlılıklarına ilişkin çocukların düşünceleri ve algılama biçimleri, kanımızca sağlıklı veriler elde etmede daha gerçekçi görünmektedir. Diğer bir deyişle, araştırma "ebeveynlere göre ebeveyn duyarlılıkları" değil, "çocuklarına göre ebeveyn duyarlılıkları" olgusu üzerine yapılandırılmıştır. Çocukların bu konudaki düşünceleri, ebeveynlerin duyarlılıklarının onlara yansıması anlamına geldiğinden daha işlevsel ve gerçekçi olacağı düşünülmüştür. Kuşkusuz, burada, anket uygulanan öğrencilerin ebeveynleri hakkında bir eksiklik ya da olumsuzluk olarak algılamaları sonucu doğruları söylemekte isteksiz davranabilecekleri olasılığını dikkate almak gerekmektedir. Ancak, bu olasılığın bütün anket uygulamaları için belirli ölçüde geçerli olduğu da bilinmektedir.

\section{Bulgular ve Değerlendirme}

Bu bölümde, ailelerin sosyo-ekonomik durumları kısaca belirlendikten sonra, ebeveynlerin çocuklarının okuma ve kütüphane kullanma alışkanlıkları konusundaki duyarlııkları irdelenmeye çalışılacaktır.

\section{Ailelerin Sosyo-Ekonomik Durumları}

Anket uygulanan öğrencilerin ebeveynleri çoğunlukla ilk ve ortaöğretim mezunudur. İlköğretim mezunu olan annelerin oranı \%48, babaların oranı ise \%34'tür. Okuma yazma bilmeyen annelerin oranı \%4,4 iken, bu oran babalar için \%1.7'dir. Üniversite mezuniyet oranlarında da babalar lehine bir durum söz konusudur. Annelerin \%14,8'i üniversite mezunu iken, bu oran babalarda \%27,6'ya yükselmektedir. Kısaca, ebeveynlerde babaların annelere göre daha eğitimli oldukları görülmektedir.

Araştırma kapsamına alınan ebeveynlerin mesleksel dağılımlarına bakıldığında, annelerin çok büyük çoğunluğunun (\%76,7) ev kadını olduğu, bunu, sırasıyla \%11,3 ile memurluk ve \%3,1 ile emekliliğin izlediği anlaşılmaktadır. Baba mesleklerinde ilk sırayı memurlar $(\% 29,7)$ alırken, işçilerin $(\% 28,8)$ ve işsizlerin diğer grupları oluşturduğu görülmektedir. Öğrenci ebeveynlerinin en 
büyük oranda 31-40 yaş grubunda toplandığı (anneler için \%70,3 ve babalar için $\% 63,4)$, bunu annelerde $20-30$ yaş grubunun $(\% 18,0)$, babalarda ise 41-50 yaş grubunun $(\% 29,1)$ izlediği anlaşılmaktadır.

Ekonomik düzeylerini belirlemek amacıyla sorulan ev ve otomobil sahipliği durumuna göre, ailelerin yarıya yakını $(\% 49,7)$ otomobilleri olduğunu ve $\% 60,2$ 'si de oturdukları evin kendilerine ait olduğunu belirtmişlerdir. Ailelerin çoğunluğunun orta gelir düzeyinde olduğu söylenebilir.

\section{Öğrencilerin* Okuma Alışkanlıkları Konusunda Ebeveyn Duyarıılığı}

\section{Öğrencilerin Kitap Okuma Sıklıkları}

Çocukların okuma alışkanlığı konusunda ebeveyn duyarlıığını çeşitli açılardan değerlendirmeye geçmeden önce, çocukların bu alışkanlıklar konusundaki durumlarını belirlemek sistematik düzen yönünden gerekli görünmektedir. Böylece, öncelikle, sorun (varsa) belirlenmiş olacak ve düşünülen ebeveyn duyarlıığını irdelemek daha anlamlı bir nitelik kazanacaktır.

Ulusal eğitim sisteminde hedeflenmesi gereken okuma alışkanlığı sıklığının ayda "2 ve daha fazla kitap okuma" (yılda 12 kez ve daha fazla) olduğu

\section{Tablo 1. Öğrencilerin Kitap Okuma Sıklıkları}

\begin{tabular}{lrr}
\hline Öğrencinin kitap okuma sıklığı & $\boldsymbol{N}$ & \% \\
\hline Hiç okumaz & 123 & 35,7 \\
2 ayda 1 kitap ve daha az & 124 & 36,0 \\
1 ayda 1 kitap & 74 & 21,5 \\
1 ayda 2 kitap ve daha fazla & 23 & 6,8 \\
\hline Toplam & $\mathbf{3 4 4}$ & $\mathbf{1 0 0 , 0}$ \\
\hline
\end{tabular}

\footnotetext{
"Çalışmada anlatımsal zorunluluklar nedeniyle denekler için, aynı anlama gelmek üzere bazen "öğrenci" bazen "çocuk" terimi kullanılmıştır. Özellikle "ebeveyn" kavramının geçtiği ifadelerde "çocuk" teriminin kullanılması tercih edilmiştir.
} 
söylenebilir ki, bu "güçlü okuma alışkanlığı" anlamına gelmektedir. Tablo 1 verilerine göre, öğrencilerin çok küçük bir bölümü $(\% 6,8)$ güçlü bir okuma alışkanlığına sahip görünmektedir. Hiç kitap okumayanlarla birlikte "zayıf" bir alışkanlığı ifade eden "2 ayda 1 kitap ve daha az" kitap okuyan öğrencilerin oranı \%71,7'ye ulaşmaktadır ki, bu, okuma alışkanlığı konusunda öğrenciler açısından ciddi bir soruna işaret etmektedir. "Orta sıklıkta" kitap okuyanlar ile "sık" okuyan öğrencilerin oranı toplam öğrencilerin üçte birini bulmamaktadır. Yani, öğrencilerde ilgili kişi ve kurumlar tarafından dikkate alınması gereken ciddi bir okuma alışkanlığı sorunu bulunmaktadır.

\section{Evde Kitaplık Olup Olmadığı}

Bir evde okumaya ilişkin duyarlılığın genel göstergelerinden birisi olarak değerlendirilebilecek kitaplık, aynı zamanda ailedeki okuma kültürünün ve ortamının doğal bir parçasıdır. Anket uygulanan öğrencilerin evlerinde bir kitaplığın (ders dışı en az 50 kitabı içeren) olup olmadığına yönelik verileri içeren tablo (Tablo 2) aşağıdadır:

Tablo 2. Ailelerin Evinde Kitaplık Bulunup Bulunmadığı

\begin{tabular}{lcc}
\hline Kitaplık var $\boldsymbol{m} \mathbf{?}$ & $\boldsymbol{N}$ & $\boldsymbol{\%}$ \\
\hline Evet & 102 & 29,7 \\
Hayır & 242 & 70,3 \\
\hline Toplam & $\mathbf{3 4 4}$ & $\mathbf{1 0 0 , 0}$ \\
\hline
\end{tabular}

Görüldüğü gibi, öğrencilerin yalnızca \%29,7'sinin evinde bir kitaplık bulunmaktadır. Öğrencilerin üçte ikisinden fazlasının evinde bir kitaplığın olmaması ruhsal ve davranışsal güdülenme açısından öğrenciler için olumsuz bir durum iken, ebeveynler açısından da bu konuda bir bilinçsizlik ve duyarsızlığın göstergesi anlamına geldiğini söylemek yanlış olmayacaktır. Evde bir kitaplık bulunmasının önemi hakkında ebeveynlerin bilinçli olduklarını söylemek güç görünmektedir. 
Ebeveynin Okul Öncesi Dönemde Çocuğuna Kitap Okuyup-Okumadığı

Çocuğun okuma alışkanlığı kazanma sürecinin en önemli aşamalarından biri sayılan ve ebeveynin okul öncesi dönemde çocuğuna kitap okuyup okumaması da ciddi bir duyarlılık-duyarsızlık ölçütüdür. Buna ilişkin veriler aşağıda verilmiştir.

Tablo 3. Ebeveynlerin Çocuklarına Kitap Okuyup Okumadıkları

\begin{tabular}{lrrrr}
\hline & \multicolumn{2}{c}{ Anne } & \multicolumn{2}{c}{ Baba } \\
Ebeveyn kitap okur muydu? & $\boldsymbol{N}$ & $\%$ & $\boldsymbol{N}$ & $\%$ \\
\hline Evet & 71 & 20,6 & 18 & 5,2 \\
Hayır & 203 & 59,1 & 244 & 70,9 \\
Bazen & 70 & 20,3 & 82 & 23,9 \\
\hline Toplam & $\mathbf{3 4 4}$ & $\mathbf{1 0 0 , 0}$ & $\mathbf{3 4 4}$ & $\mathbf{1 0 0 , 0}$ \\
\hline
\end{tabular}

Çocuğuna okul öncesinde kitap okuyan ebeveynlerin oranı gerek annelerde gerekse babalarda son derece düşük görünmektedir. Çocuğuna kitap okuyan annelerin oranı \%20,6 iken, bu oran babalar için \%5,2'dir. Babaların üçte ikisinden fazlası $(\% 70,9)$ çocuğuna okul öncesi dönemde kitap okumamıştır. Bu oldukça dikkat çekici bir orandır. Bu konuda, oranı düşük oluşuna karşın annelerin babalara göre daha olumlu görüntü çizdiği anlaşılmaktadır. Ancak, genel olarak, okul öncesi dönemde ebeveynlerin çocuklarına kitap okuma konusunda yeterli duyarlıı̆̆ı göstermedikleri söylenebilir.

Ebeveynin Çocuğa Kitap Hediye Edip Etmediği

Kitabı ve okumayı değerli bir nesne/eylem olarak algılamasında çocuğa kitap hediye edilmesi önemli bir etkendir. Denek öğrencilere göre bu konuda ebeveynlerinin durumunu yansıtan veriler Tablo 4'de yer almaktadır.

Tablo 4. Ebeveynin Çocuğuna Kitap Hediye Edip Etmediği

\begin{tabular}{|c|c|c|c|c|}
\hline \multirow[b]{2}{*}{$\begin{array}{l}\text { Ebeveyn çocuğuna kitap } \\
\text { hediye eder mi ? }\end{array}$} & \multicolumn{2}{|c|}{ Anne } & \multicolumn{2}{|c|}{ Baba } \\
\hline & $N$ & $\%$ & $N$ & $\%$ \\
\hline Evet & 91 & 26,5 & 61 & 17,7 \\
\hline Hayır & 253 & 73,5 & 283 & 82,3 \\
\hline Toplam & 344 & 100,0 & 344 & 100,0 \\
\hline
\end{tabular}


Tablo 4 incelendiğinde, annelerin yaklaşık dörtte üçü babaların ise, beşte dördü çocuklarına kitap hediye etmemektedirler. Bu konuda anneler lehine bir durum söz konusu ise de, genel görünüm oldukça olumsuzdur ve ebeveynlerin, çocuğuna kitap hediye etmede duyarsız davrandıkları söylenebilir.

\section{Ebeveynin Çocuğunu Kitabevine Götürüp Götürmediği}

Ebeveynlerin çocuklarının okuma alışkanlıkları konusundaki duyarlılıklarının bir parçası olarak, onları boş zamanlarında kitabevlerine ve/veya kitap fuarlarına götürmeleri önemli görünmektedir. Araştırmada buna ilişkin olarak elde edilen veriler durumu değerlendirmeye olanak sağlamaktadır.

Tablo 5. Ebeveynin Çocuğunu Kitabevine Götürüp Götürmediği

\begin{tabular}{lrrrr}
\hline & \multicolumn{2}{c}{ Anne } & \multicolumn{2}{c}{ Baba } \\
$\begin{array}{l}\text { Ebeveyn çocuğunu kitabevine } \\
\text { götürür mü? }\end{array}$ & $\boldsymbol{N}$ & $\%$ & $\boldsymbol{N}$ & $\%$ \\
\hline Evet & 24 & 7,0 & 23 & 6,7 \\
Hayır & 271 & 78,8 & 244 & 70,9 \\
Bazen & 49 & 14,2 & 77 & 22,4 \\
\hline Toplam & $\mathbf{3 4 4}$ & $\mathbf{1 0 0 , 0}$ & $\mathbf{3 4 4}$ & $\mathbf{1 0 0 , 0}$ \\
\hline
\end{tabular}

Annelerin \%78,8'i çocuklarını kitabevine götürmezken, bu oran babalarda \%70,9'dur. "Bazen götürme" sıklığında babalar lehine bir durum görünmektedir. Babaların \%22,4'ü, annelerin ise \%14,2'si çocuğunu "bazen" kitabevine götürmektedir. Bu konuda da ebeveynlerdeki duyarlılık düzeyinin son derece düşük olduğu ve yaklaşık \%6-7’lerde kaldığı anlaşılmaktadır. Kitap hediye etme ile kitabevine götürme konusundaki ebeveyn duyarlılık-duyarsızlık düzeyleri arasındaki benzerlik dikkat çekicidir.

\section{Ebeveynin, Kitap Seçiminde Çocuğuna Yardımcı Olup Olmadığı}

Bir anlamda yukarıdaki duyarılı̆̆ı tamamlayan bir konu da ebeveynin, çocuğunu kitap seçiminde yönlendirmesidir. Uygun kitap seçiminin çocuk için alışkanlık açısından önemi yadsınamaz. 
Tablo 6. Ebeveynin Çocuğunun Kitap Seçimine Yardımcı Olup Olmadığı Anne

Baba

Ebeveyn çocuğuna kitap N $\%$ N $\quad \%$ seçiminde yardımcı olur mu?

\begin{tabular}{lrrrr}
\hline Evet & 57 & 16,6 & 24 & 7,0 \\
Hayır & 240 & 69,7 & 175 & 50,9 \\
Bazen & 47 & 13,7 & 145 & 42,1 \\
\hline Toplam & $\mathbf{3 4 4}$ & $\mathbf{1 0 0 , 0}$ & $\mathbf{3 4 4}$ & $\mathbf{1 0 0 , 0}$ \\
\hline
\end{tabular}

Tablo 6’ya göre, çocuğuna kitap seçimi konusunda yardımcı olan anne ve baba oranı son derece düşüktür. Annelerin \%16,6'sı babaların ise \%7'si bu konuda duyarlı davranmaktadır. "Yardımcı olmama" ve "bazen yardımcı olma" seçeneklerinde baba lehine bir durumdan söz edilebilir. Ancak bir önceki tabloda (Tablo 6) annelerin çocuğunu kitabevine götürme oranı (\%7) ile burada, çocuğunun kitap seçimine yardımcı olma oranı $(\% 16,6)$ arasında bir çelişki olduğu anlaşılmaktadır. Bu çelişki, "anne, çocuğunun seçeceği kitap konusunda, ona kitabevine gitmeden yardımcı olmaktadır" biçiminde yorumlanabilir.

Ebeveynin Çocuğu ile Okuduğu Kitap Hakkında Konuşup Konuşmadığı Çocukta hem okumaya karşı ilgiyi artıran hem de ona eleştirel okuma becerisi kazandıran ebeveyn duyarlıı̆̆ının odaklanması gereken noktalardan birisi de, çocuk ile ebeveynin okunan kitap hakkında konuşmasıdır. Araştırma verilerinin ortaya çıkardığı durum aşağıdaki tabloda (Tablo 7) görülmektedir.

Tablo 7. Ebeveynin Çocuğunun Okuduğu Kitap Hakkında Onunla Konuşup Konuşmadığı

\begin{tabular}{lrrrr}
\hline & \multicolumn{2}{c}{ Anne } & \multicolumn{2}{c}{ Baba } \\
$\begin{array}{lrrr}\text { Ebeveyn, çocuğunun okuduğu } \\
\text { kitap hakkında onunla konuşur mu? }\end{array}$ & $\boldsymbol{N}$ & $\%$ & $\boldsymbol{N}$ & $\%$ \\
\hline Evet & 60 & 17,4 & 83 & 24,1 \\
Hayır & 232 & 67,5 & 203 & 59,0 \\
Bazen & 52 & 15,1 & 58 & 16,9 \\
\hline Toplam & $\mathbf{3 4 4}$ & $\mathbf{1 0 0 , 0}$ & $\mathbf{3 4 4}$ & $\mathbf{1 0 0 , 0}$ \\
\hline
\end{tabular}


Buna göre, annelerin \%17,4'ü babaların ise \% 24,1'i çocuklarının okudukları kitaplar hakkında onlarla konuşmaktadır. Buna karşın, annelerin \%67,5’i babaların \%59'u bu konuda duyarsız davranmakta ve bu duyarsızlığın annelerde daha yüksek olduğu anlaşılmaktadır. Okuma eylemini çocuğu ile paylaşma konusunda ebeveynlerin yeterince destekleyici olmadıkları söylenebilir.

Ebeveynin, Kitap Alması Için Çocuğuna Para Verip Vermediği

Ders dışı kitap alması için çocuğuna istediğinde para vermesi okuma alışkanı̆ğına ilişkin ebeveyn duyarlıı̆̆ını gösterir. Özellikle günümüzde en önemli araç durumuna gelmiş olan paranın kitap için verilmesi önemli bir duyarlıı̆̆ın ifadesidir. Bu duruma ilişkin veriler aşağıdaki tabloda (Tablo 8) yer almaktadır:

Tablo 8. Ebeveynin, Çocuğuna Kitap Alması İçin Para Verip Vermediği

\begin{tabular}{lrr}
\hline $\begin{array}{l}\text { Ebeveyn kitap alması için } \\
\text { çocuğuna para verir mi? }\end{array}$ & $\boldsymbol{N}$ & $\%$ \\
\hline Her zaman & 99 & 28,8 \\
Bazen & 239 & 69,5 \\
Hiçbir zaman & 6 & 1,7 \\
\hline Toplam & $\mathbf{3 4 4}$ & $\mathbf{1 0 0 , 0}$ \\
\hline
\end{tabular}

Tablo 8 verilerine göre, ebeveynlerin ancak yaklaşık dörtte biri çocuğuna istediğinde ders dışı kitap almak için para vermektedir. "Hiç bir zaman vermeyen" ebeveyn oranının çok düşük olması bu konuda olumlu bir duruma işaret ederken, "bazen" seçeneğinin yüksekliği $(\% 69,5)$ ebeveynlerdeki duyarlılığın sürekli ve kararlı olmadığını göstermektedir. Bu durumda ailelerin genelde orta sosyo-ekonomik düzeyde olmalarının etkisi düşünülebilir. Öte yandan, çocuk, ailenin en duyarlı olduğu varlıktır. Böyle bakıldığında, duyarsızlığın genelde bilinçsizlikten kaynaklanıyor olabileceği akla gelmektedir.

\section{Öğrencilerin Kitap Okumalarına Ebeveynlerinin Tepkisi}

Öğrencilerin boş zamanlarında ders dışı kitap okumalarına ilişkin duyarlıı̆̆ın genel bir ifadesi olarak ebeveynlerin tepkileri son derece önemli sayılmalıdır. Buna ilişkin araştırma verileri Tablo 9'da verilmiştir. 
Tablo 9. Çocuklarının Kitap Okumalarına Ebeveyn Tepkisi

\begin{tabular}{lrr}
\hline Ebeveyn tepkisi & N & $\%$ \\
\hline Hiçbir şey demezler & 229 & 66,6 \\
"Kitap okumak yerine ders çalış" derler & 16 & 4,7 \\
"Aferin!" derler. & 99 & 28,8 \\
\hline Toplam & $\mathbf{3 4 4}$ & $\mathbf{1 0 0 , 0}$ \\
\hline
\end{tabular}

Tablo 9'da öğrencilerin kitap okumalarına ilişkin ebeveyn tepkileri üç seçenekte toplanmıştır. Bunlar "tepkisizlik", "olumsuz tepki" ve "olumlu tepki" ifadeleri olarak düşünülmüştür. Buna göre bu konuda, ebeveynlerin çok büyük çoğunluğu $(\% 66,6)$ tepkisiz görünmektedir. Tepkisizliği duyarsızlık olarak değerlendirmek yanlış olmayacaktır. Olumsuz tepki verenlerin oranı $(\% 4,7)$ düşük görünmekte ancak, bu grubu da tepkisizlik seçeneği ile birlikte düşündüğümüzde, çocuğunun kitap okumasına duyarsız kalan ebeveynlerin oranı \%70'i aşmaktadır ki, bu oldukça ciddi bir olumsuzluk olarak değerlendirilebilir. Ebeveynlerin sadece dörtte birine yakını bu konuda duyarlı görünmektedir.

\section{Ebeveynlerin Kitap Okuma Sıklıkları}

Buraya kadar yapılan değerlendirmelerde, çocuklarının kitap okumaları konusunda ebeveynlerin genelde ciddi boyutlarda duyarsızlık gösterdikleri anlaşılmıştır. Bu duyarsızlıkların temel nedenlerinden birisi, onların kitap okuma alışkanlığı düzeyinden, diğer bir deyişle, okuma ile ilişkilerinden kaynaklanıyor olabilir. Kitap ile arasında güçlü ilişkinin olduğu bir ebeveynin okuma alışkanlığı konusunda bilinçli olma olasılığının daha yüksek olacağı, bunun da çocuğunun okuma alışkanlığına "duyarlı olma" biçiminde yansıyacağı söylenebilir. Aşağıdaki tablo (Tablo 10) bu ilişkiye yönelik anlamlı ipuçları sunmaktadır. 
Tablo 10. Çocuklara Göre Ebeveynlerinin Kitap Okuma Sıklıkları

\begin{tabular}{lrrrr}
\hline & \multicolumn{2}{c}{ Anne } & \multicolumn{2}{c}{ Baba } \\
Ebeveynin kitap okuma sıklığı & $\boldsymbol{N}$ & $\%$ & $\boldsymbol{N}$ & $\%$ \\
\hline Hiç okumazlar & 171 & 49,7 & 136 & 39,5 \\
Seyrek okurlar & 121 & 35,2 & 125 & 36,3 \\
Orta sıklıkta okurlar & 44 & 12,8 & 67 & 19,5 \\
Çok okurlar & 8 & 2,3 & 16 & 4,7 \\
\hline Toplam & $\mathbf{3 4 4}$ & $\mathbf{1 0 0 , 0}$ & $\mathbf{3 4 4}$ & $\mathbf{1 0 0 , 0}$ \\
\hline
\end{tabular}

Tablo 10'da yer alan veriler, çocukların gözlemlerine göre ebeveynlerin en büyük çoğunluğunun hiç kitap okumadıkları, bu oranın babalarda \%39,5 iken, annelerde \%49,7’ye yükseldiği görülmektedir. Güçlü bir okuma alışkanlığını ifade eden ve "çok okuyan" annelerin oranı sadece \%2,3 ve babaların oranı \%4,7'dir. "Seyrek okuyan" ebeveynlerle "hiç okumayan" ebeveynlerin oranı annelerde \%85'e, babalarda \%75'e kadar ulaşmaktadır. Annelerin kitap okumaya ilişkin durumları babalara göre daha olumsuz görünmektedir. Böylesine zayıf okuma alışkanlığı düzeyine sahip ebeveynlerin çocuklarına ilişkin olarak bu konuda duyarlı davranmalarını beklemek gerçekçi bir yaklaşım olmayacaktır. Bu veriler, aynı zamanda, ebeveynlerin çocuklarına bu konuda iyi birer model olamadıkları biçiminde de yorumlanabilir.

\section{Öğrencilerin Kütüphane Kullanma Alışkanlıkları Konusunda Ebeveyn Duyarlılığı}

\section{Öğrencilerin Kütüphane Kullanma Sıklıkları}

Çocukların okuma alışkanlıklarına ilişkin ebeveyn duyarlılığını irdelerken yaptığımız sistematiği kütüphane kullanma alışkanlığına yönelik olarak da uygulamak istiyoruz. Buna göre, öncelikle çocukların kütüphane kullanma alışkanlığı ile ilgili sorun (varsa) belirlenip, bu konudaki ebeveyn duyarııı̆̆ı çeşitli açılardan değerlendirilmeye çalışılacaktır. 
Tablo 11. Öğrencilerin Kütüphaneye Gitme Sıklıkları

\begin{tabular}{lrr}
\hline Öğrencinin kütüphaneye gitme sıklığı & $\boldsymbol{N}$ & $\%$ \\
\hline Hiç gitmez & 174 & 50,6 \\
2 ayda 1 kez ve daha az & 108 & 31,3 \\
1 ayda 1 kez & 47 & 13,7 \\
1 ayda 2 kez ve daha fazla & 15 & 4,4 \\
\hline Toplam & $\mathbf{3 4 4}$ & $\mathbf{1 0 0 , 0}$ \\
\hline
\end{tabular}

Tablo 11'de sunulan veriler, çocukların kütüphane kullanma alışkanlığı konusundaki durumlarının okuma alışkanlığından daha ağır bir sorun niteliği taşıdığını ortaya koymaktadır. Çocukların sadece \%4,4'ü gerçek anlamda kütüphane kullanıcısıdır. Kütüphaneye "hiç gitmeyen" öğrencilerle "zayıf" kullanımı ifade eden kütüphaneyi "2 ayda 1 kez ve daha az" kullanan öğrencilerin oranı \%81,9'a ulaşmaktadır ki, bu gerçekten yüksek bir rakamdır. Öğrencilerin beşte dördünü kütüphane kullanıcısı olmayan ya da zayıf kullanıcı olanlar oluşturmaktadırlar. Çocukların kütüphane kullanma alışkanlığı konusunda ciddi ölçülerde bir sorun söz konusudur.

\section{Öğrencilerin Kütüphane Kullanma Amaçları}

Bir önceki tablo (Tablo 11) verilerine dayanarak öğrencilerin kütüphane kullanma alışkanlıklarına ilişkin sorunun nicel durumu ortaya konmuştur. Sorunun nitelik boyutuna ışık tutabilecek veriler ise Tablo 12'de yer almaktadır.

Tablo 12. Öğrencilerin Kütüphaneye Gitme Amaçları

\begin{tabular}{lrr}
\hline Öğrencinin kütüphaneye gitme amacı & $\boldsymbol{N}$ & $\%$ \\
\hline Ödev yapmak & 238 & 69,2 \\
Ödünç kitap almak & 32 & 9,3 \\
Boş zamanı geçirmek & 53 & 15,4 \\
Arkadaşlar ile birlikte olmak & 3 & 0,9 \\
Diğer & 18 & 5,2 \\
\hline Toplam & $\mathbf{3 4 4}$ & $\mathbf{1 0 0 , 0}$ \\
\hline
\end{tabular}


Elde edilen verilere göre, öğrencilerin kütüphane kullanma alışkanlıkları konusunda bir nitelik sorunu da görünmektedir. Zira, öğrencilerin çok büyük çoğunluğu $(\% 69,2)$ kütüphaneye ödev yapmak için gitmektedir. Öğrencilerin sadece yaklaşık dörtte biri daha anlamlı amaçlarla (ödünç kitap almak-boş zamanları değerlendirmek) kütüphane kullanmaktadır. Kuşkusuz, ödev yapmak amacıyla kullanım da belirli ölçüde anlam taşımaktadır. Ancak, bu amaç kalıcı bir kullanım alışkanlığı yaratmada tercih edilir bir seçenek olarak görünmemektedir. Çünkü, öğrenci kısa süreli bir zorunluluktan dolayı kütüphaneye gelmekte, bu zorunluluk olmadığı ya da ortadan kalktığı zaman kütüphaneyi kullanmamaktadır. Oysa, diğer amaçlarda süreklilik olasılığı daha yüksek görünmektedir. Nitekim, özellikle ödünç kitap almak için zorunlu koşul olan ve aynı zamanda daha gerçekçi ve etkin bir kullanıcılığı ifade eden kütüphane üyeliğine ilişkin sorduğumuz bir başka soruya aldığımız yanıta göre, öğrencilerin sadece \%10,2'si bir kütüphaneye üye görünmektedir. Üyelik nitelikli kullanım konusunda anlamlı bir ölçüttür ve bu açıdan da öğrencilerin durumu bir nitelik sorununu içermektedir.

Bir başka soruya aldığımız yanıtlara göre, öğrencilerin \%45,1'i halk kütüphanesine, \%41,8'i okul kütüphanesine ve \%13,1'i diğer kütüphanelere gitmektedir. Ancak, amaçlar açısından kütüphane türlerine göre bir farklılık söz konusu olmamaktadır.

Kısaca, öğrenciler kütüphaneyi kendilerinde kalıcı bir alışkanlık yaratma olasılığı yüksek amaçlarla kullanmamakta, bu da kütüphane kullanma alışkanlığında bir nitelik sorununa işaret etmektedir.

\section{Ebeveynlerin Çocuklarını Kütüphaneye Götürüp Götürmedikleri}

Çocukların kütüphane kullanma alışkanlığı kazanma sürecinde ebeveynlerin duyarlıı̆̆ını yansıtan temel etkinliklerden birisi, ebeveynin çocuğunu kütüphaneye götürmesi ve dolayısıyla onu kütüphane ile tanıştırmasıdır. Aşağıdaki tablo (Tablo 13) bu konudaki verileri içermektedir. 
Tablo 13. Ebeveynin Çocuğunu Hiç Kütüphaneye Götürüp Götürmediği Anne Baba

Ebeveyn çocuğunu hiç $\begin{array}{llll}N & \text { N } & \text { N }\end{array}$ kütüphaneye götürdü mü?

\begin{tabular}{lrrrr}
\hline Evet & 55 & 16,0 & 34 & 9,9 \\
Hayır & 289 & 84,0 & 310 & 90,1 \\
\hline Toplam & $\mathbf{3 4 4}$ & $\mathbf{1 0 0 , 0}$ & $\mathbf{3 4 4}$ & $\mathbf{1 0 0 , 0}$ \\
\hline
\end{tabular}

Buna göre, ebeveynlerin çok küçük bir bölümü geçen 11-12 yılda çocuğunu bir kütüphaneye götürmüştür. Bu oran annelerde (\%16) babalara göre $(\% 9,9)$ biraz daha yüksek görünmektedir. Ancak, genelde ebeveynlerin çocuklarını kütüphaneye götürme konusunda son derece duyarsız davrandıkları anlaşılmaktadır. Böylesi bir duyarsızlıkla öğrencilerin güçlü bir kütüphane kullanma alışkanlığına sahip olma olasılıklarının yüksek olmasını beklemek gerçekçi görünmemektedir.

Öğrencilerin Kütüphaneye Gitmeleri Konusunda Ebeveyn Tepkisi Öğrencilerin kütüphane kullanımı konusunda ebeveyn duyarlıığını doğrudan yansıtan bir ölçüt olarak ebeveyn tepkisine ilişkin veriler de araştırma açısından önemli görünmektedir.

Tablo 14. Çocuklarının Kütüphaneye Gitmesi Konusunda Ebeveynlerin Tepkisi

\begin{tabular}{lrrrr}
\hline & \multicolumn{2}{c}{ Anne } & \multicolumn{2}{c}{ Baba } \\
$\begin{array}{l}\text { Çocuğun kütüphaneye gitmesi } \\
\text { konusunda ebeveynin tepkisi }\end{array}$ & $N$ & & \multicolumn{1}{c}{ N } & $\%$ \\
\hline Hiçbir şey demezler & 256 & 74,4 & 259 & 75,3 \\
"Kütüphanede ne işin var?" derler & 20 & 5,8 & 19 & 5,5 \\
"Aferin!" derler & 68 & 19,8 & 66 & 19,2 \\
\hline Toplam & $\mathbf{3 4 4}$ & $\mathbf{1 0 0 , 0}$ & $\mathbf{3 4 4}$ & $\mathbf{1 0 0 , 0}$ \\
\hline
\end{tabular}


Tablo 14'de yer alan verilere göre, gerek annelerin gerekse babaların dörtte üçü çocukların kütüphaneye gidip gitmemesi ile ilgilenmemekte, bu konuda duyarsız davranmaktadırlar. Yaklaşık \%5 oranındaki ebeveyn çocuklarının kütüphane kullanımına olumsuz tepki gösterirken, bu konuda olumlu tepki gösteren ebeveynlerin oranı annelerde \%19,8 ve babalarda \%19,2'dir. Burada sunulan veriler araştırmanın temel amaçları arasında sayılan ve ebeveynlerin sözü edilen konudaki duyarlılıklarını belirleme açısından oldukça anlamlı görünmektedir. Bu verilere dayanarak ebeveynlerin, çocuklarının kütüphane kullanma alışkanlıkları konusunda genel olarak duyarlı olmadıkları söylenebilir.

\section{Ebeveynlerin Kütüphane Kullanma Düzeyleri}

Öğrencilere göre, ebeveynlerinin kütüphaneye gitme sıklıkları aşağıdaki tabloda (Tablo 15) yansıtılmaktadır. Çocuğun, anne ve babasının kütüphaneye gitme sıklığı ve üye olup olmadığı hakkındaki düşüncesi, bir anlamda, ebeveyninin onun gözünde model olma düzeyini yansıtır. Ancak, bu aynı zamanda, ebeveynlerin incelenen konudaki duyarsızlıklarının kaynağını da bir boyutuyla ortaya koymaktadır.

Tablo 15. Çocuklarına Göre Ebeveynlerin Kütüphaneye Gitme Sıklıkları

\begin{tabular}{lrrrr}
\hline & \multicolumn{2}{c}{ Anne } & \multicolumn{2}{c}{ Baba } \\
$\begin{array}{l}\text { Ebeveynin kütüphaneye } \\
\text { gitme sıklığı }\end{array}$ & $N$ & $\%$ & N & $\%$ \\
\hline Hiç gitmezler & 282 & 82,0 & 289 & 84,0 \\
Seyrek giderler & 52 & 15,1 & 47 & 13,7 \\
Orta sıklıkta giderler & 6 & 1,7 & 5 & 1,5 \\
Sık giderler & 4 & 1,2 & 3 & 0,8 \\
\hline Toplam & $\mathbf{3 4 4}$ & $\mathbf{1 0 0 , 0}$ & $\mathbf{3 4 4}$ & $\mathbf{1 0 0 , 0}$ \\
\hline
\end{tabular}

Görüldüğü gibi, öğrencilerin yalnızca yaklaşık \%1'i ebeveyninin kütüphaneye sık gittiğini düşünmektedir. Ebeveyninin kütüphaneye hiç gitmediğini düşünen öğrencilerin oranı ise hem anneler hem de babalar için \%80'lerin üzerindedir. Bütün gitme seçeneklerindeki oranların toplamı \%16-18'e ulaşırken, elde edilen diğer verilere göre, çocukların, sadece \%3,2'sinin ebeveynlerinin bir 
kütüphaneye üye olduğunu belirtmesi durumu daha da karamsar bir noktaya, nitelik sorununa çekmektedir.

Kısaca, öğrencilere göre, ebeveynlerinin kütüphane kullanma düzey ve nitelikleri oldukça düşüktür.

\section{Öğrencilerin Okuma ve Kütüphane Kullanma Alışkanlığı Konusunda Ebeveyn Desteği}

Öğrencilere, ebeveynlerinin kendilerini okuma ve kütüphane kullanma alışkanlıkları konusunda destekleyip desteklemediklerini böyle bir soru ile doğrudan sormak, ebeveynlerinin ilgili konudaki duyarlılıklarına yönelik genel veri elde etmenin yanı sıra önceki sorulara ilişkin verilerle buradaki veriler arasında bir çelişki olup olmadığını anlamak açısından da gerekli görülmüştür.

Tablo 16. Öğrencilere Göre, Ebeveynleri, Onları Okuma ve Kütüphane Alışkanlığı Konusunda Yeterince Destekliyor mu?

\begin{tabular}{lrr}
\hline $\begin{array}{l}\text { Ebeveyn, çocuğunu okuma ve kütüphane } \\
\text { kullanma alışkanlığı konusunda destekliyor mu? }\end{array}$ & $\boldsymbol{N}$ & $\%$ \\
\hline Evet & 138 & 40,1 \\
Hayır & 206 & 59,9 \\
\hline Toplam & $\mathbf{3 4 4}$ & $\mathbf{1 0 0 , 0}$ \\
\hline
\end{tabular}

Öğrencilere, ebeveynlerinin bu araştırmada ele alınan konuda duyarlı olup olmadıkları doğrudan sorulduğunda, daha önce aynı konuda dolaylı biçimde sorulan sorulara verdikleri yanıtlardan farklı görüş bildirmişlerdir.

Büyük bir olasılıkla, soruyu "normatif" nitelikte algılamaları sonucu, ebeveynleri hakkında "olumsuz şeyler" söylemek istememişler, ebeveynlerine yönelik doğrudan olumsuz yanıtlar vermemişlerdir. Önceki sorularda dolaylı nitelikte sorulduğu için böyle bir değerlendirmeye gitme gereği duymadan görüş bildirmişlerdir. Bu nedenle, çocukların \%40,1'i diğer verilerin aksine ebeveynlerinin bu konuda duyarlı davrandığını belirtmiştir. Kuşkusuz, öğrenciler bu sorudaki "destek" kavramını ebeveynin bu alışkanlıklara "olumsuz tepki vermemesi" ya da "karşı çıkmaması" olarak genel bir çerçevede algılamış da olabilirler. Ancak, bütün bunlara karşın \%60 dolayında çocuğun ilgili konuda ebeveynlerinden destek görmediğini belirtmesi de küçümsenecek bir oran gibi görünmemektedir. 


\section{Sonuç ve Öneriler}

Araştırma bulgularına göre elde edilen sonuçlar şöyle sıralanabilir:

1. Ailelerde babaların eğitim düzeyi annelere göre daha yüksektir. Annelerde ev kadınlığı ve memurluk, babalarda da memurluk ve işçilik en yaygın meslek gruplarıdır. Ebeveynlerin çoğunluğu orta yaş grubundadır. Ailelerin çoğunluğu orta gelir düzeyindedir.

2. Çocukların ciddi bir okuma alışkanlığı sorunu bulunmaktadır.

3. Ebeveynler evde bir kitaplık oluşturma konusunda genelde duyarsızdır.

4. Ebeveynler, okul öncesi dönemde çocuklarına kitap okuma konusunda yeterli duyarlıığı göstermemektedirler.

5. Ebeveynler, çocuklarına kitap hediye etmede duyarsız davranmaktadırlar.

6. Ebeveynler, çocuklarını kitabevi ve kitap fuarlarına genelde götürmemekte, bu konuda duyarlı davranmamaktadırlar.

7. Ebeveynler, çocuklarına kitap seçimi konusunda yeterince yardımcı olmamaktadırlar.

8. Ebeveynler, çocuklarının okudukları kitaplar hakkında onlarla konuşma duyarlıı̆̆ını göstermemektedirler.

9. Ebeveynler, çocuklarına kitap almaları için para verme konusunda sürekli bir duyarlıı̆̆a sahip değildirler.

10. Ebeveynler, çocuklarının kitap okumalarına ilişkin olarak genelde duyarsız davranmaktadırlar.

11. Okuma alışkanlığına sahip olmayan ya da zayıf okuma alışkanlığına sahip ebeveynler çoğunluğu oluşturmaktadır. Ebeveynlerin, çocuklarının kitap okumalarına ilişkin duyarsızlıklarının büyük ölçüde bu durumdan kaynaklandığı düşünülmektedir.

12. Çocuklar için çok ciddi boyutlarda bir kütüphane kullanma alışkanlığı sorunu bulunmaktadır. Sorunun nicel boyutunun yanı sıra bir nitelik boyutunun da bulunduğu, kütüphanenin öğrenciler tarafından anlamlı amaçlarla kullanılmadığı söylenebilir.

13. Ebeveynler genelde çocuklarını bir kütüphane ile tanıştırmamışlardır. 
14. Ebeveynler, çocuklarının kütüphaneye gidip gitmemeleri konusunda tepkisiz kalmakta, duyarsız davranmaktadırlar.

15. Çocukları, ebeveynlerinin genelde kütüphane kullanmadıklarını düşünmektedirler.

16. Ebeveynler gerek okuma, gerekse kütüphane kullanma alışkanlığı konusunda çocuklarına ilişkin olarak genelde duyarsız davranmaktadırlar. Ebeveynlerin bu konudaki duyarsızıklarının "bütünsel" bir nitelik taşıdığı söylenebilir. Yani, ebeveynlerin çocuklarının ilgili alışkanlıkları konusunda bu çalışmada ele alınan bütün ölçütler itibariyle genel bir duyarsızlık gösterdikleri anlaşılmaktadır; bazı ölçütlerde duyarlı bazılarında ise, duyarsız oldukları gibi bir durum gözlenmemiştir. $\mathrm{Bu}$ duyarsızlıkların büyük ölçüde kendilerinin de bu alışkanlıklara ve dolayısıyla bu bilince sahip olmamalarından kaynaklandığı değerlendirilmektedir.

17. Ebeveynler çocukları için okuma ve kütüphane kullanma alışkanlıkları konusunda iyi birer model olamamaktadırlar.

Çocukların her türden alışkanlığı edinmelerinde birinci derecede etkili olan ve onlara model oluşturan ebeveynlerin, bu araştırma sonucunda ortaya çıkan duyarsızlıkları oldukça ciddi bir sorun anlamına gelmektedir. "Okumayan" ve "kütüphaneye gitmeyen" anne ve babaların "okuyan" ve "kütüphane kullanan" çocuklara sahip olma olasılıkları yüksek olamaz. Bu nedenle, kütüphanelerin bu konuda çocukların yanı sıra ve belki de daha ağırlıkla ebeveynlere yönelmesi, hedef kitle olarak önceliği ebeveynlere vermesi daha uygun olacaktır. Özellikle, annelerin ilgili konuda öncelikle bilinçlendirilmeleri bu araştırmada belirlenen olumsuzluğun giderilmesine ciddi katkılarda bulunabilecektir.

Bunun dışında, öğretmenlerin incelenen konuda çocuk-ebeveyn bütünlüğünü gözden kaçırmamaları ve ebeveynleri de okuma ve kütüphane kullanma alışkanlığına ilişkin sorunun doğal parçası olarak kabul etmeleri gerekmektedir.

$\mathrm{Bu}$ araştırma, burada belirlenen ebeveyn duyarsızlığının kaynakları/ nedenleri hakkında hem çocuk, hem de ebeveynin bakış açısıyla yapılacak yeni araştırmalarla desteklenip zenginleştirilebilir. 


\section{Kaynakça}

ALA (1978). Book reading and library usage: $A$ study of habits and perceptions. New Jersey: Gallup.

Alpay, M. (1991a). Ona kitabı sevdirelim. Kütüphane: Dünü yarına bağlayan köprü içinde (ss. 76-78). İstanbul: TKD İstanbul Şubesi.

Alpay, M. (1991b). Çocuk ne zaman okur? Kütüphane: Dünü yarına bağlayan köprü içinde (ss. 113-119). İstanbul: TKD İstanbul Şubesi.

Bamberger, R. (1990). Okuma alışkanlığını geliştirme (B. Çapar, Çev.). Ankara: Kültür Bakanlığı.

Bayram, S. (2001). Türkiye'de kitap okuma alışkanlığı. İstanbul: İstanbul Ticaret Odası.

Çıngı, H. (1990). Örnekleme kuramı. Ankara: Hacettepe Üniversitesi.

Huttner, H. (1976). Lesen in der unterstufe. Bibliothekar, 30 (2), 79-86.

Lohann, C. (1991). The creation of the reading habit in the child. Cape Librarian, 35 (4), 2-5.

Özçelebi, O. S. ve Cebecioğlu, N. S. (1990). Okuma alışkanlığı ve Türkiye. İstanbul: Milliyet Yayınları.

Özdemirci, F. (1990). Niçin az okuyoruz kamuoyu araştırması sonuçlandı. Türk Kütüphaneciliği, 4 (3), 154-155.

Özen, F. (2001). Türkiye'de okuma alışkanlığı. Ankara: Kültür Bakanlığı.

Powell, R., Taylor, M. T. ve Mcmillan, D. L. (1984). Chilhood socialization: Its effect on adult library use and adult reading. Library Quarterly, 54 (3), 245-264.

Sağlamtunç, T. (1991). Türk gençlerinin okuma alışkanlıkları. Çağdaş kütüphanecilik ve düşünce özgürlüğü üzerine içinde (ss. 141-148). İstanbul: Yapı Tasarım Üretim.

Steinberg, H. (1979). Erziehung zum lesen. Buch and Bibliothek, 31 (11/12), 958-960.

TDK (1983). Türkçe sözlük (7. bs.). Ankara: TDK.

Terweilliger, G. (1984). A sampling of parent education. Public Libraries, 23 (2), 54-56.

Yılmaz, B. (1995). Okuma sosyolojisi: Ankara'da oturanların okuma alışkanlıkları üzerine bir araşıırma. Türk Kütüphaneciliği, 9 (3), 325-336. 